\title{
Effect of nisin on shelf life of low salt Tallaga cheese
}

\author{
Ekbal M. A. Ibrahim ${ }^{1}$, Azza M. K. Sobeih ${ }^{2}$ \\ ${ }^{1}$ Department of Food Control, Faculty of Veterinary Medicine, Moshtohor, \\ Benha University, Moshtohor,Egypt \\ ${ }^{2}$ Department of Food Hygiene, Faculty of Veterinary Medicine, Kafr-El-Sheikh, \\ Tanta University, Kafr-El-Sheikh, Egypt
}

\begin{abstract}
Tallaga cheese was made from reconstituted partially skim milk powder (2\% fat) with two salt concentrations $(1 \%$ and $3 \%)$ and then $(50,100,200 \mathrm{IU} / \mathrm{ml})$ nisin were added. Control groups of both salted Tallaga cheeses were manufactured without addition of nisin. Furthermore, the two types of Tallaga cheese samples were kept in their whey at refrigerator temperature $\left(2-4^{\circ} \mathrm{C}\right)$ till signs of spoilage were observed. Periodically, the control and preserved samples were examined chemically (pH and titratable acidity) and bacteriologially (aerobic plate, psychrotrophic, coliform and aerobic sporeformer counts) to determine the influence of nisin on prolongation of their shelf life. Nisin extended the shelf- life of low- salt cheese (1\% salt) up to 8 days at concentration $100 \mathrm{IU} / \mathrm{ml}$ and up to 10 days for $200 \mathrm{IU} / \mathrm{mL}$, while; nisin-free cheese samples were spoiled after the $4^{\text {th }}$ day of refrigeration storage. On the other hand, the shelf life of $3 \%$ salt cheese was extended up to 20 days of cold storage by addition of nisin at conc. 100 and $200 \mathrm{IU} / \mathrm{ml}$. In contrast, the cheese samples of control group were deteriorated after the $8^{\text {th }}$ day of refrigerated storage. There were significant differences $(p<0.05)$ between the chemical and bacteriological profiles of low salt soft cheese as a result of storage time. Actually, the nisin had a significant destructive action on contaminating coliforms and aerobic spore forming bacteria of Tallaga cheese and lead to increase its validity period.
\end{abstract}

Tallaga cheese or white soft cheese is usually made from heated milk, which is salted to a lower level than Domiati cheese and stored in the refrigerator until consumption within two weeks (Mehanna and Rashed, 1990 and Shehata et al, 1995).

In the last few years, there was an increase in the demand for reduced-sodium food, including cheese especially for people suffering from hypertension (Albernethy, 1979 and Anonymous, 1981). In addition to its preservative effect, sodium chloride exerts a major influence on cheese composition, microflora, texture, flavour and quality (Guinee and Fox, 1993).

Nisin is an antimicrobial biopeptide produced by Lactococcus lactis subsp. lactis, produced naturally in milk and widely employed as food preservative (Bender and Bender, 1995).

Fortunately, it is non toxic, heat stable antibiotic, has a good storage stability, doesn't affect the natural product flavour or cause bad flavour and is destroyed by digestive enzymes in human (Sivasankar, 2002).

The possibility of using reconstituted dried partially skim milk for soft cheese manufacture aiming for improving body, texture (organoleptic characters), functional properties and nutritional values of the produced cheese by raising its total solid content is recommended (Abou-Donia, 1991 and El-Sheikh et al., 2001). On the other hand, Chen et al., (1991) and Zommar (2000) found that the protein content of cheese increased by lowering it is fat content and consequently cheese becomes of high nutritive value. Additionally, milk fat (saturated fat) is associated with health problems including; high blood cholesterol, coronary heart disease and some kinds of cancer (USD HHS, 1988 and Giese, 1996). Milk fat was also reported to reduce the antimcrobial effect of nisin (Bhatti et al., 2004 and Grade et al., 2004).

Therefore, the present work was carried out to study the effect of nisin at different concentration $(50,100,200, \mathrm{IU} / \mathrm{ml})$ as a biopreservative on shelf life of experimentally manufactured Tallaga cheese with low fat $(2 \%)$ and low salt (1\% and 3\% sodium chloride) during storage at refrigerator temperature.

\section{Material and Methods}

Fresh, unripened, low salt white soft cheese (Tallaga cheese) was manufactured as described by Mehanna and Rashed (1990) and El-Sheikh et al. (2001) with slight modification as follows:

A total of $16 \mathrm{~kg}$ of reconstituted partially skim milk powder $\left(2 \%\right.$ fat) were heated at $42^{\circ} \mathrm{C}$, 
where $\mathrm{CaCl}_{2}(0.02 \%)$ and rennet powder $(3 \mathrm{~g}$ $/ 100 \mathrm{~kg}$ milk) were added. The bulk volume of cheese mix were divided into two portions, the first $8 \mathrm{Kg}$ were salted with $1 \%$ sodium chloride and the other portion with $3 \%$, sodium chloride. Each portion $(8 \mathrm{~kg})$ was subdivided into 4 patches $(2 \mathrm{~kg}$ each), then nisin [(AGCH- 9470 Bucks $(1000 \mathrm{IU} / \mathrm{mg})]$ was added to each patch $(2 \mathrm{~kg})$ at concentration of $0,50,100,200 \mathrm{IU} / \mathrm{ml}$ respectively.

Each $2 \mathrm{~kg}$ of cheese mix were kept at 38 $42^{\circ} \mathrm{C}$ for $2-3$ hours till curd formation, then kept to drain for 24-36 hours in previously sterilized stainless steal frames lined with cheese cloth. The formed cheese was packaged in presterilized glass jars and kept in their whey at refrigerator temperature $\left(2-4^{\circ} \mathrm{C}\right)$. The cheese samples were examined fresh (zero time) and at intervals of 2, 4, 6, 8 and 10 days for $1 \%$ salted cheese and at 4, 8, 12, 16, 18 and 20 days for $3 \%$ salted cheese till the sings of spoilage were observed. The cheese samples were examined chemically for titratable acidity (T.A\%) and $\mathrm{pH}$ according to Pearson (1984) and bacteriologically after preparation of the sample as described by BSI (1984).

The bacteriological examination includes determination of Aerobic plate count (APC), psychotrophic bacterial count and coliform count as described by APHA (1992) as well as aerobic spore former count as described by (Collins and Lyne, 1984).

\section{Results and Discussion}

Table (1): Effect of nisin on chemical profile of low salt Tallaga cheese with $1 \%$ salt.

\begin{tabular}{|c|c|c|c|c|c|c|c|c|}
\hline \multirow[b]{2}{*}{$\begin{array}{l}\text { Storage } \\
\text { time }\end{array}$} & \multicolumn{4}{|c|}{ T.A. \% } & \multicolumn{4}{|c|}{ PH } \\
\hline & Control & 50 & 100 & $200 *$ & Control & 50 & 100 & $200 *$ \\
\hline Zero time & 0.05 & 0.03 & 0.03 & 0.01 & 6.84 & 6.83 & 6.83 & 6.88 \\
\hline 2 days & 0.05 & 0.04 & 0.03 & 0.02 & 6.79 & 6.77 & 6.76 & 6.81 \\
\hline 4 days & 0.06 & 0.05 & 0.04 & 0.02 & 6.56 & 6.47 & 6.31 & 6.42 \\
\hline 6 days & $?$ & $?$ & 0.04 & 0.03 & $?$ & $?$ & 6.24 & 6.26 \\
\hline 8 days & $?$ & $?$ & 0.06 & 0.04 & $?$ & $?$ & 6.03 & 6.00 \\
\hline 10 days & $?$ & $?$ & $?$ & 0.06 & $?$ & $?$ & $?$ & 5.85 \\
\hline
\end{tabular}

Control $=$ Cheese without nisin. $\quad ?=$ Samples organoleptically revealed signs of deterioration.

$*=$ Significant differences $(\mathrm{p}<0.05)$

Table (2): Effect of nisin on chemical profile of low salt Tallaga cheese with 3\% salt.

\begin{tabular}{|c|c|c|c|c|c|c|c|c|}
\hline \multirow{2}{*}{$\begin{array}{l}\text { Storage } \\
\text { time }\end{array}$} & \multicolumn{4}{|c|}{ T.A. \% } & \multicolumn{4}{|c|}{ pH } \\
\hline & Control & 50 & 100 & $200 *$ & Control & 50 & 100 & $200 *$ \\
\hline Zero time & 0.05 & 0.05 & 0.04 & 0.04 & 6.72 & 6.72 & 6.74 & 6.77 \\
\hline 4 days & 0.06 & 0.06 & 0.05 & 0.05 & 6.56 & 6.57 & 6.54 & 6.53 \\
\hline 8 days & 0.07 & 0.06 & 0.06 & 0.06 & 6.42 & 6.31 & 6.39 & 6.29 \\
\hline 12 days & $?$ & 0.07 & 0.07 & 0.07 & ? & 6.19 & 5.59 & 6.09 \\
\hline 16 days & ? & $?$ & 0.07 & 0.07 & ? & $?$ & 5.54 & 6.00 \\
\hline 20 days & ? & ? & 0.11 & 0.10 & ? & ? & 5.38 & 5.85 \\
\hline
\end{tabular}

Control $=$ Cheese without nisin. $\quad ?=$ Samples organoleptically revealed signs of deterioration.

$*=$ Significant differences $(\mathrm{p}<0.05)$ 
Table (3): Effect of nisin on bacteriological profile of Tallaga cheese with $1 \%$ salt.

\begin{tabular}{|c|c|c|c|c|c|c|c|c|c|c|c|c|c|c|c|c|}
\hline \multirow{2}{*}{$\begin{array}{l}\text { Nisin } \\
(I U / m l)\end{array}$} & \multicolumn{4}{|c|}{ APC (cfu/g) } & \multicolumn{4}{|c|}{ Psychrotrophic count (cfu/g) } & \multicolumn{4}{|c|}{ Coliform count (MPN/g) } & \multicolumn{4}{|c|}{ Aerobic sporeformers count. (cfu/g) } \\
\hline & Control & 50 & 100 & 200* & Control & 50 & 100 & 200* & Control & 50 & 100 & 200* & Control & 50 & 100 & 200* \\
\hline Zero time & $4.5 \times 10^{6}$ & $6 \times 10^{5}$ & $6.5 \times 10^{5}$ & $5 \times 10^{6}$ & $1.5 \times 10^{5}$ & $1,1 \times 10^{5}$ & $8.3 \times 10^{4}$ & $4 \times 10^{4}$ & $5 \times 10^{5}$ & $1.1 \times 10^{5}$ & $1 \times 10^{5}$ & $1 \times 10^{5}$ & $7.1 \times 10^{4}$ & $6 \times 10^{4}$ & $5.3 \times 10^{4}$ & $1 \times 10^{4}$ \\
\hline 2 days & $7.7 \times 10^{6}$ & $3.4 \times 10^{6}$ & $4.2 \times 10^{5}$ & $8.2 \times 10^{4}$ & $8.1 \times 10^{5}$ & $4.5 \times 10^{5}$ & $2.8 \times 10^{4}$ & $1.2 \times 10^{4}$ & $8.9 \times 10^{5}$ & $1 \times 10^{5}$ & $2 \times 10^{4}$ & $1.1 \times 10^{4}$ & $6.3 \times 10^{4}$ & $5 \times 10^{4}$ & $1.6 \times 10^{4}$ & $1 \times 10^{4}$ \\
\hline 4 days & $8.5 \times 10^{7}$ & $2.4 \times 10^{6}$ & $1.2 \times 10^{6}$ & $7.3 \times 10^{5}$ & $1 \times 10^{6}$ & $5.7 \times 10^{5}$ & $3 \times 10^{4}$ & $1 \times 10^{4}$ & $8.3 \times 10^{5}$ & $1.4 \times 10^{4}$ & $7.5 \times 10^{3}$ & $1.5 \times 10^{3}$ & $6.5 \times 10^{3}$ & $5.5 \times 10^{3}$ & $1.5 \times 10^{3}$ & $8.1 \times 10^{2}$ \\
\hline 6 days & $?$ & $?$ & $4.7 \times 10^{6}$ & $1.1 \times 10^{6}$ & $?$ & $?$ & $9.6 \times 10^{5}$ & $1 \times 10^{5}$ & $?$ & $?$ & $2.1 \times 10^{3}$ & $1 \times 10^{2}$ & $?$ & $?$ & $1.1 \times 10^{3}$ & $2 \times 10^{2}$ \\
\hline 8 days & $?$ & $?$ & $7 \times 10^{7}$ & $4.5 \times 10^{6}$ & $?$ & $?$ & $1 \times 10^{6}$ & $4.8 \times 10^{5}$ & $?$ & $?$ & $2 \times 10^{2}$ & $1 \times 10^{2}$ & $?$ & $?$ & $4.3 \times 10^{2}$ & $1 \times 10^{2}$ \\
\hline 10 days & $?$ & $?$ & $?$ & $3 \times 10^{7}$ & $?$ & $?$ & $?$ & $3.4 \times 10^{6}$ & $?$ & $?$ & $?$ & $2 \times 10$ & $?$ & $?$ & $?$ & $2 \times 10$ \\
\hline
\end{tabular}

Table (4): Effect of nisin on bacteriological profile of Tallaga cheese with $3 \%$ salt.

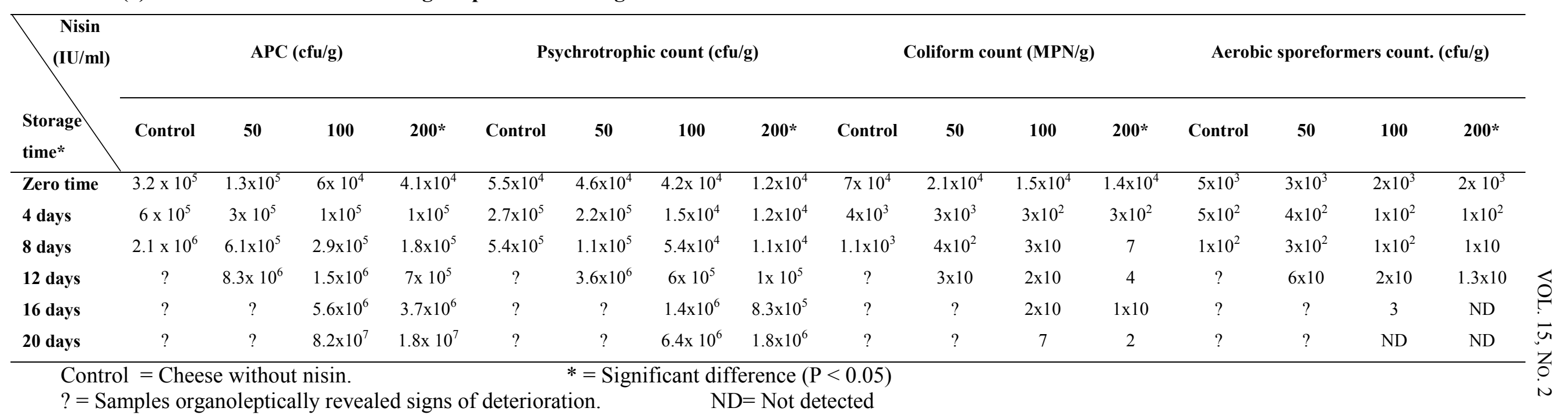


Inspection of Table $(1,2)$ revealed that the T. A\% of control and 50,100 as well as 200 $\mathrm{IU} / \mathrm{ml}$ nisin treated cheese for ( $1 \%$ salted cheese) at the day of manufacturing were $0.05,0.03$, 0.03 and 0.01 , but were $0.05,0.05,0.04$ and 0.04 (for 3\% salted cheese) at nisin conc. of 0,50 , $100 \& 200 \mathrm{IU} / \mathrm{ml}$ respectively.

Increasing $\mathrm{T}$. A. of the examined cheese samples, were relatively low as the samples were stored at $5-7^{\circ} \mathrm{C}$ (Hamed et al., 1992). The T. A\% reached 0.06 and $0.05 \%$ for nisin -free cheese and cheese with $50 \mathrm{IU} / \mathrm{mL}$ nisin, respectively at the $4^{\text {th }}$ day of refrigeration. The T. A $\%$ was 0.06 for salted cheese $(1 \%)$ treated with 100 and 200 $\mathrm{IU} / \mathrm{ml}$ nisin at the $8^{\text {th }}$ and $10^{\text {th }}$ day of manufacture, while for $3 \%$ salted cheese, T. A \% reached $0.07,0.07,0.11$ and 0.10 for cheese treated with $0,50,100$ and $200 \mathrm{IU} / \mathrm{ml}$ nisin at the $8^{\text {th }}, 12^{\text {th }}, 20^{\text {th }}$ and $20^{\text {th }}$ day of refrigeration (Table 2).

During storage, the T. A\% of all cheese samples were increased as the storage period progressed, while the $\mathrm{pH}$ values showed an opposite trend. These results agreed with those recorded by EL-Sissi (1996) and El-Abd et al., (2003).

On the other hand, the $\mathrm{pH}$ values decreased gradually by increasing the sodium chloride concentration as a result of increasing the acidity (Ramet et al., 1983 and Abou-El-Nour, 1998). This can be attributed to a base exchange reaction of $\mathrm{Na}^{+}$for free $\mathrm{NH}_{3}^{+}$groups in the casein micelles with liberation of $\mathrm{H}^{+}$(Ling, 1963).

The $\mathrm{pH}$ values at zero time for nisin treated cheese samples (with 1\% salt) at conc. 0, 50, 100 and $200 \mathrm{IU} / \mathrm{ml}$ were $6.84,6.83,6.83$ and 6.88 , respectively (Table 1), while the $\mathrm{pH}$ decreased to 6.56 and 6.47 at the $4^{\text {th }}$ day for control and 50 $\mathrm{IU} / \mathrm{ml}$ nisin treated cheese, but 6.03 and 5.85 at the $8^{\text {th }}$ and $10^{\text {th }}$ days of storage at $2-4^{\circ} \mathrm{C}$ for 100 and $200 \mathrm{IU} / \mathrm{ml}$ nisin treated cheese, respectively. The $\mathrm{pH}$ values for fresh Tallaga cheese samples with $3 \%$ salt were $6.72,6.72,6.74$ and 6.77 for $0,50,100$ and $200 \mathrm{IU} / \mathrm{ml}$ nisin treated cheese samples, respectively and decreased to 6.42 and 6.19 at the $8^{\text {th }}$ and $12^{\text {th }}$, days for control and 50 $\mathrm{IU} / \mathrm{ml}$ nisin treated samples, but to 5.38 and 5.85 at the $20^{\text {th }}$ day for 100 and $200 \mathrm{IU} / \mathrm{ml}$ nisin treated cheese respectively.

Nearly similar results were reported by ElSheikh et al. (2001), while lower results were reported by Abou El-Nour et al. (2004).

The relatively high $\mathrm{pH}$ at zero time of the cheese may be attributed to the time of drainage as the retention of calcium phosphate increased within the curd matrix, which in turn would act as a buffering agent against the developed acidity in cheese (Johnson et al., 1998).

Additionally, low-fat cheese always had lower $\mathrm{pH}$ value than fresh full-fat cheeses (Patel et al., 1986 and Zommar, 2000). The gradual decreasing of $\mathrm{pH}$ values may be refereed to the gradual increasing of salt concentration and dry matter that accompanied with moisture losses (Zommar, 2000; El-Sheikh et al., 2001 and Abou El-Nour et al., 2004). Nisin activity is enhanced at $\mathrm{pH}$ ranged from 5 to 6.4. (Beard et al., 1999 and Mansour et al., 1999)

Concerning to the total bacterial counts for 1 $\%$ salted Tallaga cheese samples, Table (3) shows that APC at the day of manufacturing were $4.5 \times 10^{6}, 6 \times 10^{5}, 6.5 \times 10^{5}$ and $5 \times 10^{6}$ cfu/g for $0,50,100,200 \mathrm{IU} / \mathrm{ml}$ nisin treated cheese samples respectively. The cheese samples became organoleptically deteriorated when the APC reached $8.5 \times 10^{7}$ and $2.4 \times 10^{6} \mathrm{cfu} / \mathrm{ml}$ at the $4^{\text {th }}$ day of storage at $2-4^{\circ} \mathrm{C}$ for control and nisin treated cheese at level $50 \mathrm{IU} / \mathrm{ml}$ respectively, while for nisin treated cheese at conc. 100 and $200 \mathrm{IU} / \mathrm{ml}$, the shelf life of $1 \%$ salted cheese extended to the $8^{\text {th }}$ and $10^{\text {th }}$ day of refrigerated storage when APC reached $7 \times 10^{7}$ and $3 \times 10^{7} \mathrm{cfu} / \mathrm{g}$ respectively.

Table (4) shows that the APC (cfu/g) for $3 \%$ salted cheese were $3.2 \times 10^{5}, 1.3 \times 10^{5}, 6 \times 10^{4}$ and $4.1 \times 10^{4}$ for $0,50,100$ and $200 \mathrm{IU} / \mathrm{ml}$ nisin treated cheese respectively at zero time and the shelf life extended to the $8^{\text {th }}$ for control cheese samples when APC increased up to $2.1 \times 10^{6}$ and to the $12^{\text {th }}$ day for $50 \mathrm{IU} / \mathrm{mL}$ nisin treated cheese when the APC reached $8.3 \times 10^{6}$, while, for 100 and $200 \mathrm{IU} / \mathrm{ml}$ nisin treated cheese the shelf life extended to the $20^{\text {th }}$ day of refrigeration as APC reached to $8.2 \times 10^{7}$ and $1.8 \times 10^{7}$ respectively.

Nearly similar results were reported by Hamed et al. (1992) and El-Abd et al. (2003). It was obvious that the APC were lower in cheese samples salted with $3 \% \mathrm{NaCl}$ than those with $1 \% \mathrm{NaCl}$ and this referred to the inhibitory effect of salt $(\mathrm{NaCl})$ and the developed acidity on the existed microflora (Abd El-Salam et al., 1990; El-Sissi, 1996 and El-Abd et al., 2003).

Sodium chloride acts as a food preservative and its effectiveness is directly proportional to its concentration. It acts by tying up the moisture by reducing the solubility of oxygen in water molecules and/or the harmful effect of chloride ion on some microorganisms and thus having an 
adverse effect on microbial growth (Guinee and Fox, 1993 and Sivasankar, 2002).

There was a synergistic effect between the sodium chloride and the added nisin at level 200 $\mathrm{IU} / \mathrm{ml}$, resulting in 5-1og reduction of the bacterial count (Terebiznik et al., 2002).

At the same trend, psychrotrophic bacteria increased during progressive storage coming nearly parallel to APC.

Reviewing Table $(3,4)$ the psychrotrophic count for $0,50,100,200 \mathrm{IU} / \mathrm{ml}$ nisin treated cheese were $1.5 \times 10^{5}, 1.1 \times 10^{5}, 8.3 \times 10^{4}$ and 4 x $10^{4} \mathrm{cfu} / \mathrm{g}$ (for $1 \%$ salted cheese) and $5.5 \times 10^{4}$, $4.6 \times 10^{4}, 4.2 \times 10^{4}$ and $1.2 \times 10^{4} \mathrm{cfu} / \mathrm{g}$ (for $3 \%$ salted cheese) at the day of manufacturing.

For control cheese samples with $1 \%$ salt, psychrotrophic count (cfu/g) increased to $1 \times 10^{6}$ at the $4^{\text {th }}$ day of storage at $2-4^{\circ} \mathrm{C}$. At the $4^{\text {th }}, 8^{\text {th }}$ and $10^{\text {th }}$ days of refrigeration the psychrotrophic count reached $5.7 \times 10^{5}, 1 \times 10^{6}$ and $3.4 \times 10^{6}$ for 50, 100 and $200 \mathrm{IU} / \mathrm{ml}$ nisin treated cheese samples (Table 3), also the count reached to 5.4 $\times 10^{5}, 3.6 \times 10^{6}, 6.4 \times 10^{6}$ and $1.8 \times 10^{6}$ for 0,50 , 100 and $200 \mathrm{IU} / \mathrm{ml}$ nisin treated cheese with $3 \%$ $\mathrm{NaCl}$ (Table 4).

The high psychrotrophic count of the examined Tallaga cheese samples may be attributed to the high APC and the bacteriostatic activity of nisin on Gram-positive but not on Gram-negative bacteria (Thomas et al., 1998 and Masschalck et al., 2001).

Regarding coliforms, data in (Table 3) show clearly that the count $(\mathrm{MPN} / \mathrm{g})$ for $1 \%$ salted cheese samples, were $5 \times 10^{5}, 1.1 \times 10^{5}, 1 \times 10^{5}$ and $1 \times 10^{5}$ at zero time and decreased to $8.3 \times$ $10^{5}, 1.4 \times 10^{4}, 2 \times 10^{2}$ and $2 \times 10$ for $0,50,100$ and $200 \mathrm{IU} / \mathrm{ml}$ nisin treated cheese at the time of which the signs of cheese deterioration appeared.

For 3\% salted Tallaga cheese samples, the coliform counts (MPN/g) were $7 \times 10^{4}, 2.1 \times 10^{4}$, $1.5 \times 10^{4}$ and $1.4 \times 10^{4}$ at zero time and decreased to $1.1 \times 10^{3}, 3 \times 10,7$ and 2 for 0,50 , 100 and $200 \mathrm{IU} / \mathrm{ml}$ nisin treated cheese at the $8^{\text {th }}$, $12^{\text {th }}, 20^{\text {th }}$ and $20^{\text {th }}$ days of refrigeration. Lower findings were reported by El-Abd et al. (2003).

The high coliform counts in the examined cheese samples at zero time may be attributed to the initial coliform count of the skim-milk powder used in cheese manufacture. Hegazi (1972) stated that presence of salt at rate less than $9 \%$ could not prevent the growth and activity of coliform in Domiati cheese. This suggestion confirmed the effect of nisin on coliform bacteria.
El-Abd et al. (2003) recommended the addition of mixed culture starter of mesophilic Lactococci and Lactobacillus casei to decrease the coliform count in low-salt cheese as a result of the attained high acidity and production of some antimicrobial substances.

Nisin has a wide spectrum activity against most Gram-positive bacteria, including spore formers (Zottola and Smith, 1993 and Delves and Gasson, 1994). It is recommended to be added to low-fat foods intended for heating to reduce the thermal resistance of selected bacterial spores while maintaining the product quality, functionality and shelf stability (Dufrenne et al., 1995; Beard et al., 1999 and Wandling et al., 1999).

In this respect, Table $(3,4)$ declared that the aerobic spore formers $(\mathrm{cfu} / \mathrm{g})$ for $1 \%$ salted cheese samples with $0,50,100$ and $200 \mathrm{IU} / \mathrm{ml}$ nisin were $7.1 \times 10^{4}, 6 \times 10^{4}, 5.3 \times 10^{4}$ and $1 \times$ $10^{4}$, while for $3 \%$ salted cheese samples were $5 \mathrm{x}$ $10^{3}, 3 \times 10^{3}, 2 \times 10^{3}$ and $2 \times 10^{3}$ at the time of manufacture. Regarding to $1 \%$ salted cheese stored at $2-4^{\circ} \mathrm{C}$, the count of aerobic spore formers decreased to $6.5 \times 10^{3}$ and $5.5 \times 10^{3}$ for control and $50 \mathrm{IU} / \mathrm{ml}$ nisin treated cheese samples, respectively. After 8 and 10 days of storage for 100 and $200 \mathrm{IU} / \mathrm{ml}$ nisin treated cheese samples, the count reached $4.3 \times 10^{2}$ and $2 \times 10 \mathrm{cfu} / \mathrm{g}$ respectively (Table 3 )

For 3\% salted cheese after 8 and 12 days of storage, the aerobic spore forming count decreased to $1 \times 10^{2}$ and $6 \times 10 \mathrm{cfu} / \mathrm{g}$ for nisinfree cheese and nisin treated $(50 \mathrm{IU} / \mathrm{ml})$. While, Tallaga cheese samples with 100 and $200 \mathrm{IU} / \mathrm{ml}$ nisin, the shelf life of such cheese samples extended to $20^{\text {th }}$ days of cold storage without any aerobic spore forming count.

In general, nisin had significant effect $(\mathrm{p}<$ 0.05 ) on bacteriological aspect of Tallaga cheese during refrigeration. The spore formers decreased as the $\mathrm{pH}$ value increased, showing total inhibition at pH 6.0 (Mansour et al., 1999).

The combination of reduced heat treatment (RHT) of milk at $117^{\circ} \mathrm{C}$ for 2 seconds, nisin and low storage temperatures were suggested to be potential against Gram-positive spore-forming bacteria and to extend shelf life of dairy products (Wirjantoro et al., 2001).

From the foregoing results, this study concluded that sodium chloride salt has great effect on controlling the chemical and bacteriological deterioration of Tallaga cheese especially at concentration of $3 \%$. Such cheese 
can be consumed safely up to 8 days while those cheese samples with $1 \% \mathrm{NaCl}$ can be consumed till 4 days only of refrigeration. Incorporation of nisin prolonged the shelf life of $1 \%$ salted cheese up to 8 days at conc. $100 \mathrm{IU} / \mathrm{ml}$ and up to 10 days at conc. $200 \mathrm{IU} / \mathrm{ml}$. On the other hand nisin extended the shelf life of $3 \%$ salted cheese up to 20 days at refrigeration $\left(2-4^{\circ} \mathrm{C}\right)$.

\section{References}

Abd El-Salam, M. H.; Mahfouz, M. B.; Al-Khamy, A. F.; Abdel Ghanie, S. and Sharaf, O. M. (1990): Microbiological quality of salted whey. Egypt. J. Dairy. Sci., 18: 327-334.

Abou-Donia, S. A. (1991): Manufacture of Egypitan, soft and pickled cheeses. In: Feta and related cheeses. Edited by: Robinson, R. K. and Tamime, A.Y. Ellis Horwood. Limited, Sussex. New York.

Abou El-Nour, A. M. (1998): Effect of sodium chloride, a mixture of sodium chloride and potassium chloride on the curd characteristics. Egypt. J. of Diary Sci., 26: 193-202.

Abou El-Nour, A. M.; Abbas, F. M.; Khalil, R. A. M. and El-Safty, M. S. (2004): Modified manufacturing procedure for improving the quality of low fat Ras cheese. Egypt. J. Dairy Sci., 32: 141-52.

Albernethy, I. D. (1979): Sodium and potassium in high blood pressure. Food Technol. J. 33: 57.

American Public Health Association 'A. P. H. A' (1992): Standard methods for the examination of dairy products. INC., $16^{\text {th }}$ Ed., New York.

Anonymous (1981): Dietary salt. J. Food Technol., 34: 85. Beard, B. M.; Sheldon, B. W. and Foegeding, P. M. (1999): Thermal resistance of bacterial spores in milkbased beverages supplemented with nisin. J. Food. Prot. 62 (5): 484-491.

Bender, A. E. and Bender, B. (1995): "X refer- nisin'. A Dictionary of Food and Nutrition. Oxford Univ., Press, C.

Bhatti, M.; Veeramachaneni, A. and Shlelef, L. A. (2004): Factors affecting the antilisterial effects of nisin in milk. Int. J. Food Microbiol., 97 (2): 215-219.

BSI "British Standards Institiution" (1984): Microbiological examination of dairy prupsoses. BS 4285: section. 2. 1.

Chen, C. M.; Johnson, M. E. and Olson, N. F. (1991): Relationship between manufacturing practices and quality of reduced fat cheddar cheese. J. Dairy Sci., 74: 95.

Collins, C. H. and Lyne, P. M. (1984): Microbiological Methods. $5^{\text {th }}$ ed., Butter and Tanner Ltd., Rome and London.

Delves-Broughton, J. and Gasson, M. J. (1994): "Nisin". P. 99- 132, In: Dillon, V. M. and Board, R. G. ed., Natural antimicrobial systems in food preservation. CAB. International, Wallingford. U.K.

Dufrenne, J.; Dijwaard, M.; Te-Giffel, M.; Beumer, R. and Notermans, S. (1995): Characteristics of some psychotrophic Bacillus cereus isolates. Int. J. Food. Microbiol., 27 (2-3): 175-183.

El-Abd, M. M.; Abd El-Fattah, A. M.; Osman, S. G. and Abd El-Kader, R.S. (2003): Effect of some lactic acid bacteria on the properties of low salt Domiati cheese. Egypt. J. Dairy Sci., 31: 125-138.

El-Sheikh, M. M.; Farrag, A. F.; Shahein, N. M. and ElShibiny, S. (2001): Low fat Domiati cheese with particulated whey protein concentrate (PWPC). Egypt. J. Dairy Sci., 29: 331-342.
El-Sissi, M. G. M. (1996): Studies on Nasr Cheese a newly ripened white soft cheese. Egypt. J. Dairy Sci., 24 : 235246.

Giese, J. (1996): Fats, oils and fat replacers. Food Technol., 1: 51- 60.

Grade, S.; Avila, M.; Medina, M. and Nunez, M. (2004): Fast induction of nisin resistance in Streptococcus thermophilus INIA 463 during growth in milk. Int. J. Food Microbiol., 96 (2): 165-172.

Guinee, T. P. and Fox, P. F. (1993): Salt in cheese: physical, chemical and biological aspects. In: Cheese: Chemistry, physics and microbiology. Edited by Fox, P.F. volume: 1 General aspects. $2^{\text {nd }}$ ed., Chapman, \& Hall. New York.

Hamed, A. I.; El-Saify, N. A.; Farag, S. I. and Orsi, F. (1992): Effect of pasteurization and storage conditions on the microbiological, chemical and organoleptic properties of Domiati cheese during pickling. Egypt. J. Dairy Sci., 20: 177-190.

Hegazi, F. Z. M. (1972): Bacteriological studies of fresh and pickled white cheese. M. Sc. Thesis, Assuit. Univ., Egypt.

Johnson, M. E.; Steele, J. L.; Broadbent, J. and Weimer, B. C. (1998): Manufacture of Gouda cheese and flavour development in reduced- fat cheddar cheese. Aust. J. Dairy. Technol., 1: 53- 67.

Ling, E. R. (1963): A Textbook of Dairy Chemistry. Vol. II. Chapman and Hall, Ltd. London.

Mansour, M.; Amri, D.; Bouttefroy, A.; Linder, M. and Milliere, J. B. (1999): Inhibition of Bacillus licheniformis spore growth in milk by nisin, monolaurin and $\mathrm{pH}$ combinations. J. Appl. Microbiol., 86 (2): 311-324.

Masschalck, B.; Van Houdt, R. and Michiels, C. W. (2001): High pressure increases bactericidal activity and spectrum of lactoferrin and nisin. Int. J. Food. Microbiol. 64 (3): 325-332.

Mehanna, A. S. and Rashed, M. A. (1990): An attempt to improve the keeping quality of Tallaga cheese by using milk treated with carbon dioxide. Egypt. J. Dairy Sci., 18: 377-388.

Patel, G. C.; Vyas, S. H. and Upadhyay, K. G. (1986): Evaluation of Mozzarella cheese made from buffalo milk using direct acidification technique. Ind. J. Dairy Sci., 39: 394.

Pearson, D. (1984): Chemical analysis of Foods. $8^{\text {th }}$ ed., Churchill Livingston, Edinburgh, London.

Ramet, J. P.; El-Mayda, E. and Weber, F. (1983): Influence of salting of reconstituted milk on curdling by rennet. J. Tex. Studies 14: 11

Shehata, A. E.; Gaafar, A. M. and Hussein, G. A. M. (1995): Fate of enterotoxigenic S. aureus in Tallaga cheese. $6^{\text {th }}$ Egypt. Conf. Dairy Sci., Technol., Cairo, Egypt 4-6: 169.

Sivasankar, B. (2002): Food processing and presentation. Chapter: 8. Food additives. Prentice-Hall of India Private Limited, New Delhi. 110001.

Terebiznik, M.; Jagus, R.; Cerrutti, P.; de Huergo, M. S. and Pilosof, A. M. (2002): Inactivation of Escherichia coli by a combination of nisin, pulsed electric fields and water activity reduction by sodium chloride. J. Food Prot., 65 (8): 1253-1258.

Thomas, L. V.; Davies, E. A.; Delves- Broughton, J. and Wimpenny, J. W. (1998): Synergistic effect of sucrose fatty acid esters on nisin inhibition of Gram-positive bacteria J. Appl. Microbiol., 85 (6): 1013-1022. 
USDHHS (1988): The surgeon general's report on nutrition and health. Publ., No. 88- 50210. US. Govt. Print. Office, Washington, D.C.

Wandling, L. R.; Sheldon, B. W. and Foegeding, P. M. (1999): Nisin in milk sensitizes Bacillus spores to heat and prevents recovery of survivors. J. Food Prot., 62 (5): 492498.

Wirjantoro, T. I.; Lewis, M. J.; Grandison, A. S.; Williams, G. C. and Delves-Broughton, J. (2001): The effect of nisin on the keeping quality of reduced heattreated milks. J. Food Prot., 64 (2): 213-219.

Zommar, O. A. (2000): Technological studies on mozzarella cheese. Ph. D. Thesis Ain-Shams, Univ.

Zottola, E. A. and Smith, L. B. (1993): Growth and survival of undesirable bacteria in cheese. In: Cheese: chemistry, physics and microbiology. Volume: 1 General aspects. Edited by Fox, P.F. $2^{\text {nd }}$ ed., Chapman \& Hall. New York. 